\title{
SUMMER DEFICIT-IRRIGATION STRATEGIES IN A HEDGEROW OLIVE ORCHARD CV. 'ARBEQUINA'. EFFECT ON FRUIT CHARACTERISTICS AND YIELD
}

\author{
María Gómez del Campo ${ }^{1}$ \\ ${ }^{1}$ Dpto. Producción Vegetal: Fitotecnia. Universidad Politécnica de Madrid. Ciudad Universitaria sn. 28040 \\ Madrid. Spain.maria.gomezdelcampo@upm.es, Tel.+34913363714, Fax: +34913365400.
}

\begin{abstract}
Maximum production in hedgerow olive orchards is likely not achieved with maximum evapotranspiration over the long-term. Thus, regulated deficit irrigation (RDI) should be considered as a management option. Four irrigation treatments were evaluated during the summer when olive is most drought resistant. Control (CON) was irrigated to maintain the rootzone close to field capacity. Severe water deficit was applied by irrigating 30\% CON from end of fruit drop to end July (DI-J) and from end July until beginning of oil synthesis (DI-A). Less severe water deficit was applied during July and August (DI-JA) by irrigating 50\% CON. Flowering, fruiting, abscission, fruit development, fresh and dry weight of fruits, and oil production were evaluated. There were not significant differences in number of buds initiated, number of fruits per inflorescence and fruit drop. Oil production was significantly different between irrigation treatments in all experimental years. CON produced more oil and fruit with higher oil\% than DI-A and DI-JA. Oil production of DI-J was not significantly reduced compared to CON and oil\% was greater. DI-J was the most effective RDI strategy; with 16\% less applied water relative to CON average loss in oil production of $8 \%$ was not significantly different to CON. While DI-JA saved most water (27\%), oil production was reduced by $15 \%$. Greatest loss in oil production (21\%) was observed in DI-A with water saving of 22\%.
\end{abstract}

\section{Introduction}

Olive has been grown for over 4000 years, mostly in low density orchards (100/ha) in areas of low rainfall, and mostly without irrigation. Production methods are now changing rapidly. Requirements for new orchards are for early yield after planting, high yield when established, and mechanization, especially for harvesting. Hedgerow olive orchards were designed to achieve these objectives. The first experimental olive hedgerow orchard was planted in Italy (Morettini 1972) but commercial hedgerow orchards, also called "superintensive" (714 to 1975 olive/ha), now harvested with modified, "over-row" grape harvesters, have been planted in Spain since the early 1990s. Olive hedgerow orchards now occupy more than 40,000 ha worldwide, mainly under irrigation. Further expansion is limited by availability of water for irrigation because suitable areas are mostly located in areas where water is scare and competition with other uses is great and increasing.

Although olive tree is well adapted to waterlimited environment by avoidance (control of transpiration and by water uptake by root system) and tolerance (sustains long periods of water deficit and maintains metabolic activity enough to survive) (Connor 2005), it responds positively to irrigation even applied at deficit (Fernandez and Moreno 1999). Many experiments have been carried out in traditional olive orchards but their responses to water have limited applicability to new intensive orchards (Connor 2005), mainly because hedgerow canopies occupy less volume while having higher external surface areas.

Grattan et al. (2006) observed that maximum production of hedgerow olive orchards was not achieved with maximum irrigation and that RDI strategies could be applied to advantage. In these strategies, less water is applied than is needed to satisfy maximum crop evapotranspiration. RDI was first used in peach production in Australia (Chalmers et al. 1981). This technique seeks to save water and control vegetative growth in orchards with no detrimental effect on production. To this end, controlled deficit is applied during periods so that vegetative growth is restricted by water stress, while fruit production is not. The appropriate intensity and duration of water deficit must be determined experimentally. In Prunus sp., RDI is applied from initial fruit growth until pit hardening and then later during the postharvest period. In Citrus sp. by contrast, the most successful period is during summer, after fruit drop (Ruiz-Sanchez et al. 2010). 
Irrigation experiments with olive have identified two especially sensitive periods when irrigation deficit does significantly reduce production. First, in spring, from budburst until fruit drop, when many physiological processes from differentiation of inflorescences and flower structures, to flowering, fruit set, and fruit drop determine the ultimate fruit number (Pastor 2005). Second, at end of summer and beginning of autumn until harvest, active photosynthesis is required for production and transport of the sugar-alcohol mannitol to fruit for oil synthesis. Tognetti et al. (2006) in southern Italy observed that oil production was linearly related to irrigation amount during early autumn. In olive, the main objective in RDI is not to control vegetative growth, as in peach (Chalmers et al. 1981), because shoot growth occurs mainly in spring and slightly in autumn, coinciding with the first and second periods of drought sensitivity. Summer is the period when irrigation water can best be conserved with least reduction in fruit and oil production (Goldhamer 1999), but the timing and intensity of deficit irrigation during that time has yet to be established. Previous studies have evaluated deficit irrigation during both summer and autumn, and found that deficit irrigation affects oil synthesis (Gucci et al. 2007; MartinVertedor et al. 2011; Moriana et al. 2003; Motilva et al. 2000; Patumi et al. 2002).

The objective of the experiment reported here is to determine an appropriate summer RDI strategy for hedgerow olive orchards in terms of timing and severity. For this, treatments were designed to measure the effect on fruit and oil production of severe deficits in summer, one commencing just after fruit drop and continuing to the end of July, and a second during the subsequent month of August but terminating before the commencement of the oil accumulation period. A third irrigation treatment applied a less severe deficit, but during both of these periods (July and August). This information is required to improve the irrigation management in hedgerow olive orchards.

\section{Materials and Methods}

\section{The site and the orchard}

The experiment was conducted in a 45 ha commercial orchard planted with cv. 'Arbequina' in 1997 in Puebla de Montalbán, Toledo, Spain (latitude $39^{\circ} 48^{\prime} \mathrm{N}$; longitude $04^{\circ} 27^{\prime} \mathrm{W}$; altitude
$516 \mathrm{~m}$ ) at a spacing of $4 \times 2 \mathrm{~m}$ (1250 olive/ha) with rows oriented $20^{\circ} \mathrm{N}$ of EW. At the time of the experiment, hedgerows were $2.3 \mathrm{~m}$ high and $1.1 \mathrm{~m}$ wide. The area is characterized by low rainfall (average annual rainfall of $395 \mathrm{~mm}$ ), high evaporative demand (average annual ETo of 1180 $\mathrm{mm}$ ), and a long frost period (November to March). Soil was clay loam (Haploxeralf typic) with an effective rooting depth of $0.60 \mathrm{~m}$ comprising three layers each of $20 \mathrm{~cm}$ depth. For the three horizons in sequence, texture was clay loam, clay loam and sandy-clay loam, respectively, and stones occupied 9, 9 and $12 \%$ of soil volume.

A weather station at the site registered wind speed and direction, rainfall, temperature, humidity, and global radiation every 30 minutes and calculated reference evapotranspiration (ETo) by the PenmanMonteith method (Allen et al. 1998).

Weeds were controlled using a non-residual herbicide, and fertilizer was applied according to leaf analyses carried out each year in July.

\section{Irrigation treatments}

Four irrigation treatments (CON, DI-J, DI-A and DI-JA) were maintained during 2007 to 2009 seasons in an area of $5600 \mathrm{~m}^{2}$ in a completely randomized design of four blocks. Each replicate comprised 36 trees (12 trees in each of 3 adjacent rows). The central 10 trees in the centre row of each replication were used for measurement. Three of these trees were identified and used only for final harvest. The remaining 26 trees provided a border. Each row of trees was irrigated from a single line with drip emitters of $3 \mathrm{~L} / \mathrm{h}$ spaced 0.50 m apart.

CON trees were irrigated according to continuous readings of 6 Watermark ${ }^{\mathrm{TM}}$ sensors connected to a data logger (Irrometer, CA, USA) located in pairs at $0.3 \mathrm{~m}$ depth and $0.3 \mathrm{~m}$ from emitters adjacent to trunks of 3 representative trees. Irrigations of $6 \mathrm{~h}$ duration were applied from spring until 15 August when sensors indicated a mean soil water potential of $-0.03 \mathrm{MPa}$. Then, in order to harden the trees for Autumn frost, the threshold potential for irrigation was lowered to 0.06 MPa until end of the irrigation season. Detailed measurements at two sites revealed that irrigation of $6 \mathrm{~h}$ duration wetted the soil to $0.6 \mathrm{~m}$ depth, and therefore to the potential effective rooting depth, without excessive drainage.

All treatments were irrigated as CON except in summer. DI-J and DI-A were irrigated with $30 \%$ of the water applied to CON during July and 
August, respectively. DI-JA was irrigated with $50 \%$ of CON during both July and August. Amounts of irrigation applied differed from year to year according to climatic conditions. CON received 221, 284 and $402 \mathrm{~mm}$ in 2007, 2008 and 2009 seasons, respectively. Relative to CON, reductions in water applied to DI-J, DI-A and DIJA were 16, 22 and 27\%. Mean midday stem water potential of CON was $-1.98 \mathrm{MPa}$ while in DI-J, DI-A and DI-JA it fell to $-2.75,-3.54$ and -3.15 $\mathrm{MPa}$ in July, August and July-August, respectively. Further details of irrigation treatments are shown in Table 1.

\section{Yield and its development}

Phenological development was recorded each year as occurrence of mean budburst, full bloom, pit hardening, and veraison (Sanz-Cortes et al. 2002). Additional data were collected to define sequences of yield development in 2008 and 2009 as follows. Three stems were selected and tagged at random on south sides of 3 trees for measurement of stem length and bud number. Later, in sequence, counts were made of number of inflorescences per stem (07/05/2008 and $24 / 04 / 2009$ ) and number of fruits per stem at the end of fruit drop (10/07/2008 and 18/06/2009) and harvest (05/11/2008 and 30/10/2009). These observations were used to calculate percentages of buds that developed an inflorescence, inflorescences that set fruit on at least one flower, mean number of fruits per inflorescence, fruit drop, and number of fruits at harvest per bud.

Fruit growth was recorded during 2007 and 2008 by sampling 100 olives every $2-4$ weeks from 23/08 until $12 / 11 / 2007$ and $03 / 09$ to 05/11/2008 (commercial harvest date) from mid height of the south sides of hedgerows in each repetition, but avoiding trees identified for final harvest. Three sub samples of $25 \mathrm{~g}$ were weighed fresh and again after oven-drying at $105^{\circ} \mathrm{C}$. Oil content was measured on dry sub samples by nuclear magnetic resonance (MiniSpec MQ-10, Bruker, Madison, USA) using the method described by del Rio and Romero (1999).

Final harvests were made on 12/11/2007, 05/11/2008 and 30/10/2009 when fruit was removed from the 3 selected trees per treatment and repetition. Yield of each tree was weighed fresh on collection from which a sample of $450 \mathrm{~g}$ was extracted. Samples were divided into subsamples of $25 \mathrm{~g}$ that were each reweighed and again after drying, fruit were counted, and maturity index was determined based on colour of skin and pulp (Ferreira 1979). Oil content was determined on fresh and dry basis. Fruit number per tree was calculated from total production and mean fruit mass.

Samples of olives of each harvested tree were extracted separately in an Abencor analyzer (Comercial Abengoa S.A., Seville, Spain) comprising three units that together simulate industrial extraction of virgin olive oil at laboratory scale. Oil extractability was calculated as percentage extracted of total oil measured by nuclear magnetic resonance, considering $0.916 \mathrm{~kg}$ $\mathrm{L}^{-1}$ the olive oil density at ambient temperature.

Data were subjected to analysis of variance using MSTAT-C (University of Michigan, USA). Year effect was analysed as factorial design. Least significant differences $(\mathrm{P}<0.05)$ were used to separate means of parameters evaluated between irrigation treatments using Duncan's multiple range test.

\section{Results}

\section{Environmental conditions}

Weather data are summarized in Fig. 1 as monthly minimum and maximum temperatures $\left({ }^{\circ} \mathrm{C}\right)$ and monthly totals of rainfall $(\mathrm{mm})$ and reference evapotranspiration (ETo, mm). Rainfall and ETo during individual irrigation periods are presented in Table 1.

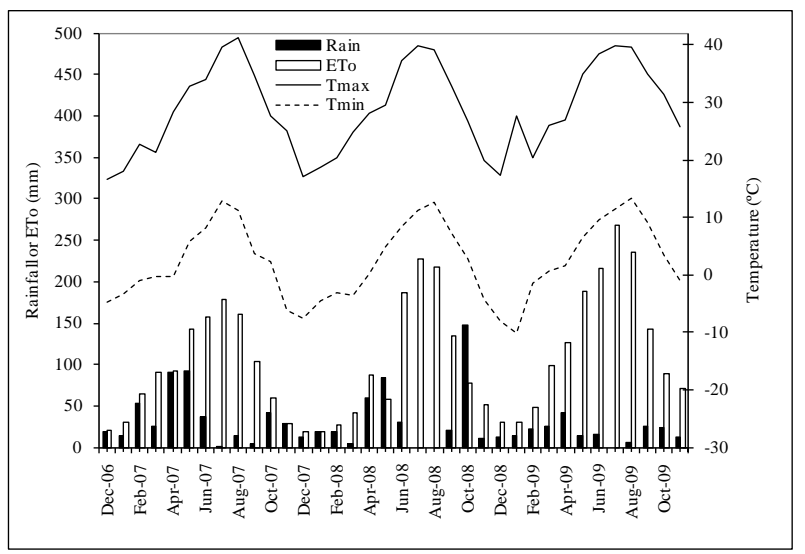

Figure 1. Monthly rainfall, reference evapotranspiration, and minimum and maximum temperatures from December 2006 until November 2009 at the experimental orchard located in Puebla de Montalbán (Toledo, Spain).

July and August were the hottest months and December and January the coldest. Highest 
temperature $\left(39.8^{\circ} \mathrm{C}\right)$ was recorded on two days $(17 / 07 / 2008$ and $26 / 07 / 2009)$ and lowest $\left(-10.2^{\circ} \mathrm{C}\right)$ on 5 January 2009. Rainfall varied between years, from $212 \mathrm{~mm}$ in 2009 to $422 \mathrm{~mm}$ in 2007. Annual distribution was also variable. Rainfall occurred mainly in April, May and October, while June, July, and August were typically dry. No rainfall was recorded in July or August 2008 even though total rainfall that year was high $(443 \mathrm{~mm})$. High rainfall of 2007 was received mostly in Spring but highest monthly rainfall occurred in 2008 Autumn (147 $\mathrm{mm}$ in October). Conditions remained highly evaporative throughout the experiment with cumulative ETo of 1126, 1178 and $1543 \mathrm{~mm}$ from December until November for 2007, 2008 and 2009 seasons.

Table 1. Climatic characteristics and irrigation applied to control $(\mathrm{CON})$ and three deficit-irrigation treatments (DI-J, DI-A and DI-JA) from December 1 until November 30 of 2007, 2008 and 2009 season.

\begin{tabular}{|c|c|c|c|c|c|c|c|}
\hline & \multicolumn{7}{|c|}{ Irrigation (mm) } \\
\hline & $\begin{array}{l}\text { Summer } \\
\text { period }\end{array}$ & $\begin{array}{c}\text { Rainfall } \\
(\mathrm{mm})\end{array}$ & $\begin{array}{l}\text { ETo } \\
(\mathrm{mm})\end{array}$ & $\mathrm{CON}$ & DI-J & DI-A & DI-JA \\
\hline $01 / 12-17 / 05 / 07$ & & 230 & 373 & - & - & - & - \\
\hline $18 / 05-24 / 06 / 07$ & & 103 & 193 & 27 & 27 & 27 & 26 \\
\hline $25 / 06-22 / 07 / 07$ & $1^{\mathrm{st}}$ & 1 & 164 & 47 & 15 & 47 & 24 \\
\hline $23 / 07-02 / 09 / 07$ & $2^{\text {nd }}$ & 14 & 219 & 89 & 85 & 39 & 45 \\
\hline 03/09 - 22/10/07 & & 37 & 133 & 58 & 58 & 58 & 58 \\
\hline $23 / 10-12 / 11 / 07$ & & 8 & 26 & - & - & - & - \\
\hline $13 / 11-30 / 11 / 07$ & & 29 & 18 & - & - & - & - \\
\hline Total & & 422 & 1126 & 221 & 185 & 171 & 153 \\
\hline$\overline{01 / 12-23 / 03 / 08}$ & & 52 & 153 & - & - & - & - \\
\hline $24 / 03-29 / 06 / 08$ & & 174 & 413 & 52 & 49 & 49 & 49 \\
\hline $30 / 06-24 / 07 / 08$ & $1^{\mathrm{st}}$ & 0 & 171 & 56 & 14 & 56 & 28 \\
\hline $25 / 07-31 / 08 / 08$ & $2^{\text {nd }}$ & 0 & 230 & 98 & 99 & 30 & 50 \\
\hline 01/09 - 07/10/08 & & 23 & 133 & 78 & 78 & 78 & 78 \\
\hline $08 / 10-05 / 11 / 08$ & & 149 & 52 & - & - & - & - \\
\hline $04 / 11-30 / 11 / 08$ & & 45 & 26 & - & - & - & - \\
\hline Total & & 443 & 1178 & 284 & 240 & 213 & 205 \\
\hline $01 / 12-26 / 03 / 09$ & & 54 & 192 & - & - & - & - \\
\hline $27 / 03-18 / 06 / 09$ & & 89 & 451 & 81 & 81 & 81 & 81 \\
\hline $19 / 06-21 / 07 / 09$ & $1^{\mathrm{st}}$ & 0 & 269 & 99 & 30 & 99 & 50 \\
\hline $22 / 07$ - 24/08/09 & $2^{\text {nd }}$ & 5 & 282 & 113 & 113 & 34 & 56 \\
\hline $25 / 08-16 / 10 / 09$ & & 30 & 247 & 109 & 109 & 121 & 121 \\
\hline $17 / 10-30 / 10 / 09$ & & 20 & 31 & - & - & - & - \\
\hline $31 / 10-30 / 11 / 09$ & & 14 & 71 & - & - & - & - \\
\hline Total & & 212 & 1543 & 402 & 333 & 335 & 308 \\
\hline
\end{tabular}

Phenological development, and reproductive components

All treatments, except DI-J, displayed similar development patterns in successive years. In those treatments, budburst occurred at the beginning of March (01/03/07, 10/03/2008 and 10/03/2009), bloom from end of May to beginning of June (28/05/2007, 01/06/2008 and 24/05/2009), and pit hardening in July (22/07/2007, 31/07/2008 and 12/07/2009). In DI-J, pit hardening was delayed until 03/09/2008 and 24/07/2009. Fruits were harvested in all treatments on the same dates, viz. at veraison on $12 / 11 / 2007$ but before veraison on 5/11/2008 and 30/10/2009. Growing Degree Days (GDD) were calculated from 1 January using a base temperature of $7^{\circ} \mathrm{C}$ (Orlandi et al. 2010). Budburst occurred after 77, 59 and 66 and bloom after 668, 543 and $639^{\circ} \mathrm{Cd}$ in 2007, 2008 and 2009, respectively. Pit hardening in CON, DI-A and DIAJ was after 1506, 1577 and 1481 while corresponding durations for DI-J were 1506, 2169 and $1719^{\circ} \mathrm{Cd}$. Harvest was after 2923, 2806 and $3226^{\circ} \mathrm{Cd}$ for the three years, respectively.

Observations on bud development on oneyear-old stems made during 2008 and 2009 are presented in Table 2. Again, few differences were recorded between treatments. Seasonal shoot growth was 13 and $8 \mathrm{~cm}$ and number of buds developed was 8 and 6 in 2008 and 2009 seasons, respectively. Overall in this experiment $50 \%$ of buds developed an inflorescence and 53\% produced at least one fruit, of which only $4 \%$ dropped. Year had a significant effect but interaction between year and irrigation treatment was not significant on these evaluated parameters. Analysing all the years together, DI-J stems developed significantly more fertile inflorescences and fruits per bud than DI-A, but were not different to CON or DI-JA. Analysing year by year, the only difference established between treatments was in number of fruits per bud in 2009. In that year, DI-J stems developed significantly more fruits per bud (0.5) than other treatments (0.3). This was a result of higher, but not individually significant differences in, number of buds initiated, fertile inflorescences, and number of fruits per inflorescence.

\section{Fruit growth and development}

Olive dry weight and oil content were determined within each irrigation treatment from 23/08 until 12/11/2007 and from 03/09 to 05/11/2008 (commercial harvest date) (Fig. 2). Olive weight and oil content increased sharply until end of October and then slowed until harvest in both years. Mean weekly olive weight increments were 2.4 and $1.2 \mathrm{~g} / 100$ fruits before and after the end October, respectively. Increments in oil content were 2.0 and $1.1 \mathrm{~g} / 100$ fruits and 3.7, 1.5 (\% dry weight). From September until harvest, increments in olive weight and oil content per fruit were 44 and $86 \%$ of the final values, respectively. 
During that period, olive dry weight increased mainly due to oil content, only $9 \%$ of fruit dry matter (discounting oil) was produced during these last months before harvest.

Table 2. Reproductive components in a control (CON) and three deficit-irrigation treatments (DI-J, DI-A and DI-JA) during 2008 and 2009. Percentage of winter buds that developed an inflorescence (buds initiated), percentage of inflorescences that developed one or more fruits (fertile inflorescence), number of fruits per fertile inflorescence, percentage of fruit dropped and number of fruits per bud.

\begin{tabular}{lccccc} 
& & \multicolumn{5}{c}{ Irrigation treatments } \\
& Year & CON & DI-J & DI-A & DI-JA \\
\hline Buds initiated (\%) & 2008 & 38 & 47 & 38 & 48 \\
& 2009 & 58 & 67 & 55 & 48 \\
\hline Fertile inflorescence (\%) & $2008-2009$ & 48 & 57 & 46 & 48 \\
\hline & 2008 & 61 & 54 & 43 & 54 \\
& 2009 & 45 & 69 & 43 & 51 \\
\hline Fruits per fertile inflorescence & $2008-2009$ & $53 \mathrm{ab}$ & $61 \mathrm{a}$ & $43 \mathrm{~b}$ & $53 \mathrm{ab}$ \\
\hline (number) & 2008 & 1.83 & 1.49 & 1.04 & 1.49 \\
\hline & 2009 & 1.22 & 1.38 & 1.11 & 1.29 \\
\hline Fruit drop (\%) & $2008-2009$ & 1.53 & 1.43 & 1.08 & 1.39 \\
\hline & 2008 & 5 & 0 & 1 & 4 \\
& 2009 & 7 & 4 & 10 & 3 \\
\hline Fruits per bud (number) & $2008-2009$ & 6 & 2 & 5 & 3 \\
\hline & 2008 & 0.4 & 0.5 & 0.4 & 0.5 \\
& 2009 & $0.3 \mathrm{~b}$ & $0.5 \mathrm{a}$ & $0.3 \mathrm{~b}$ & $0.3 \mathrm{~b}$ \\
\hline & $2008-2009$ & $0.4 \mathrm{ab}$ & $0.5 \mathrm{a}$ & $0.3 \mathrm{~b}$ & $0.4 \mathrm{ab}$ \\
\hline
\end{tabular}

Means for each file followed by different letters are significantly different at $\mathrm{P}<0.05$, according to Duncan's multiple range test. Values are means of 36 replicates.

Deficit irrigation during summer caused different fruit growth during two months before harvest (September-November) when all treatments again received the same irrigation. Rainfall during summer 2007 may have attenuated treatment effects because olive dry weight was significantly different on two occasions of measurement while no differences in oil were observed. In 2008, however, treatments significantly affected fruit characteristics at each measurement. Fruits in CON were significantly bigger than in DI-J and DI-JA. During the entire oil accumulation period, oil content was significantly different between treatments. The order was until the middle of October: CON > DI-J $>$ DI-A > DI-JA. Latter the order was CON > DIA $>$ DI-J $>$ DI-JA.

\section{Fruit characteristics at harvest}

Fruit characteristics of size (dry weight), oil content (weight and \% dry weight), \% water, oil extractability and maturity index are presented in Table 3. In a combined analysis, year significantly modified all fruit characteristic parameters evaluated. Interaction between year and irrigation treatment was not significant, except for oil content (per dry weight) and water content. Olives were harvested nearly black in 2007 (average maturity index $\mathrm{MI}=2.98$ ) and green-yellow in 2008 and 2009 (average MI $=0.37$ and 1.54). In 2007 and 2009 olives were bigger (0.60 g/fruit) with higher oil content (46\%) than in $2008(0.42$ g/fruit and 42\%). In 2008, fruit water content was higher and oil extractability was lower. Fruit characteristics at harvest were consistent with those harvested at mid tree height on south sides of hedgerows for the sequential data presented in Fig. 2.

Table 3. Fruit characteristics at harvest in a control $(\mathrm{CON})$ and three deficit-irrigation treatments (DI-J, DIA and DI-JA) in 2007, 2008 and 2009.

\begin{tabular}{lccccc} 
& Year & $\begin{array}{c}\text { Irrigation } \\
\text { treatment } \\
\text { CON }\end{array}$ & DI-J & DI-A & DI-JA \\
\hline $\begin{array}{l}\text { Olive dry weight } \\
\text { (g/fruit) }\end{array}$ & 2007 & 0.62 & 0.54 & 0.61 & 0.53 \\
& 2008 & $0.46 \mathrm{a}$ & $0.42 \mathrm{ab}$ & $0.45 \mathrm{a}$ & $0.36 \mathrm{~b}$ \\
& 2009 & $0.74 \mathrm{a}$ & $0.53 \mathrm{c}$ & $0.63 \mathrm{~b}$ & $0.52 \mathrm{c}$ \\
\hline & $2007-2009$ & $0.61 \mathrm{a}$ & $0.49 \mathrm{~b}$ & $0.56 \mathrm{a}$ & $0.47 \mathrm{~b}$ \\
\hline & 2007 & 0.30 & 0.26 & 0.29 & 0.25 \\
& 2008 & $0.19 \mathrm{a}$ & $0.19 \mathrm{a}$ & $0.17 \mathrm{ab}$ & $0.15 \mathrm{~b}$ \\
& 2009 & $0.35 \mathrm{a}$ & $0.25 \mathrm{bc}$ & $0.26 \mathrm{~b}$ & $0.23 \mathrm{c}$ \\
\hline & $2007-2009$ & $0.28 \mathrm{a}$ & $0.23 \mathrm{bc}$ & $0.24 \mathrm{~b}$ & $0.21 \mathrm{c}$ \\
\hline Oil content (g/fruit) & 2007 & 48.7 & 47.5 & 46.7 & 47.0 \\
& 2008 & $41.0 \mathrm{~b}$ & $45.8 \mathrm{a}$ & $38.1 \mathrm{c}$ & $41.3 \mathrm{~b}$ \\
matter) & 2009 & $46.3 \mathrm{a}$ & $46.6 \mathrm{a}$ & $41.4 \mathrm{~b}$ & $43.0 \mathrm{~b}$ \\
\hline & $2007-2009$ & $45.3 \mathrm{~b}$ & $46.6 \mathrm{a}$ & $42.1 \mathrm{~d}$ & $43.8 \mathrm{c}$ \\
\hline Maturity index & 2007 & 2.86 & 2.82 & 3.30 & 2.94 \\
& 2008 & 0.36 & 0.39 & 0.45 & 0.27 \\
& 2009 & 1.66 & 1.52 & 1.5 & 1.48 \\
\hline & $2007-2009$ & 1.63 & 1.58 & 1.75 & 1.56 \\
\hline Water content (\%) & 2007 & 45.2 & 45.5 & 44.3 & 44.5 \\
& 2008 & $56.1 \mathrm{~b}$ & $58.5 \mathrm{a}$ & $56.2 \mathrm{~b}$ & $56.8 \mathrm{~b}$ \\
& 2009 & 47.3 & 51.1 & 48.8 & 46.3 \\
\hline & $2007-2009$ & $49.5 \mathrm{c}$ & $51.7 \mathrm{a}$ & $49.8 \mathrm{~b}$ & $49.2 \mathrm{~d}$ \\
\hline & 2007 & 76.9 & 76.3 & 80.9 & 77.5 \\
& 2008 & 60.8 & 60.5 & 60.0 & 58.4 \\
& $2009-2009$ & 74.7 & 71.2 & 74.2 & 73.5 \\
\hline & & 69.3 & 71.7 & 69.8 \\
\hline
\end{tabular}

Means for each file followed by different letters are significantly different at $\mathrm{P}<0.05$, according to Duncan's multiple range test. Values are means of 12 replicates.

CON and DI-A developed larger fruits with greater oil content (g/fruit) than DI-JA. Yearly analyses also revealed that fruit size and oil content did not respond significantly to irrigation treatment in 2007 but did so in 2008 and 2009. In those latter years, CON and DI-A olives were $30 \%$ bigger than DI-JA. Oil content (\% dry weight) was 
$13 \%$ greater in DI-J than DI-A. Oil content per fruit in CON was $26 \%$ greater than DI-JA.

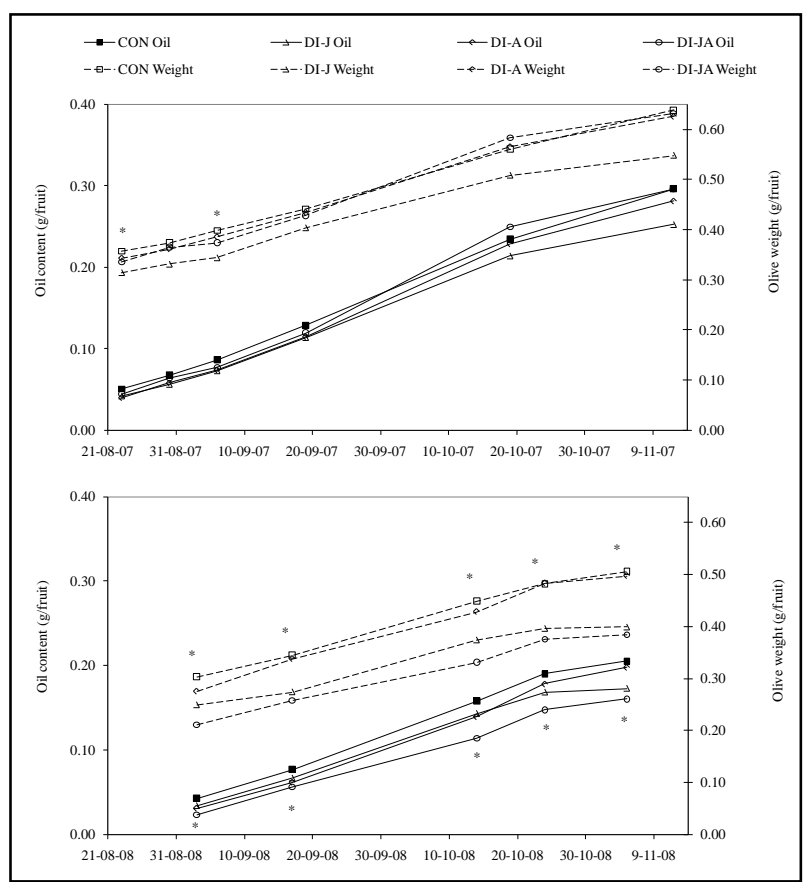

Figure 2. Evolution of olive oil content and dry weight on a control (CON) and three deficit-irrigation treatments (DI-J, DI-A and DI-JA) during 2007 and 2008. *, significant differences at $\mathrm{P}<0.05$. Values are means of 4 replicates.

\section{Oil yield and its components}

Olive fruit number, yield as fresh and dry weight, and oil production are presented in Table 4. Year significantly modified yield and its components. There was no significant interaction between year and irrigation treatment in any of the evaluated parameters. Highest yields were achieved in 2007 and 2008 (more than $11 \mathrm{t} / \mathrm{ha}$ ), but in 2009 yield fell to $9 \mathrm{t} / \mathrm{ha}$. This fall is attributed to low temperatures in winter $\left(-10.2^{\circ} \mathrm{C}\right)$ that defoliated trees and reduced fruit number (Fig. 1).

Irrigation treatment significantly affected oil production. CON trees produced more oil than DIA every year and more than DI-JA in 2007 and 2009. DI-J production was not reduced significantly relative to CON in any individual year. Mean values over the three years were 2665, 2447, 2144, and $2285 \mathrm{~kg} /$ ha for CON, DI-J, DI-A and DI-JA, respectively. On this basis, oil yield of DI-J was less than CON, but greater than DI-A.

Analysis here seeks to evaluate this response in terms of (1) effect of irrigation on fruit production and its components of fruit number and fruit size, and (2) response of oil content that translates biomass production to oil.

Table 4. Olive production in fresh and dry weight, oil production and number of fruits in a control (CON) and three deficit-irrigation treatments (DI-J, DI-A and DIJA).

\begin{tabular}{lccccc} 
& & \multicolumn{4}{c}{ Irrigation treatment } \\
& Year & CON & DI-J & DI-A & DI-JA \\
\hline $\begin{array}{l}\text { Olive production fresh } \\
\text { weight (kg/ha) }\end{array}$ & 2007 & 12415 & 11720 & 10701 & 11158 \\
& 2008 & 13913 & 12513 & 11812 & 12012 \\
& 2009 & 8892 & 8485 & 8175 & 7820 \\
\hline & $2007-2009$ & $11740 \mathrm{a}$ & $10906 \mathrm{ab}$ & $10231 \mathrm{~b}$ & $10330 \mathrm{~b}$ \\
\hline $\begin{array}{l}\text { Olive production dry weight } \\
\text { (kg/ha) }\end{array}$ & 2007 & 6821 & 6394 & 5961 & 6181 \\
& 2008 & 6097 & 5201 & 5133 & 5179 \\
& 2009 & 4687 & 4134 & 4193 & 4181 \\
\hline Oil production (kg/ha) & $2007-2009$ & $5868 \mathrm{a}$ & $5243 \mathrm{~b}$ & $5096 \mathrm{~b}$ & $5180 \mathrm{~b}$ \\
\hline & 2007 & $3308 \mathrm{a}$ & $3027 \mathrm{ab}$ & $2767 \mathrm{~b}$ & $2908 \mathrm{~b}$ \\
& 2008 & $2503 \mathrm{a}$ & $2380 \mathrm{ab}$ & $1933 \mathrm{~b}$ & $2130 \mathrm{ab}$ \\
& $2007-2009$ & $2185 \mathrm{a}$ & $1937 \mathrm{ab}$ & $1691 \mathrm{~b}$ & $1813 \mathrm{~b}$ \\
\hline Olive fruits (number/tree) & 2007 & 9203 & 9770 & 8266 & 9596 \\
& 2008 & 10716 & 10215 & 9891 & 11548 \\
& 2009 & 5154 & 6324 & 5226 & 6513 \\
\hline & $2007-2009$ & 8358 & 8770 & 7794 & 9219 \\
\hline
\end{tabular}

Means for each file followed by different letters are significantly different at $\mathrm{P}<0.05$, according to Duncan's multiple range test. Values are means of 12 replicates.

Oil yield is the product of fruit number and fruit oil content. In these, as in other data (Gucci et al. 2007), oil production is more closely related to fruit number than fruit oil content and the two parameters are not independent. Fruit number is a more important determinant of yield because it varies relatively over a much wider range than does fruit oil content and because as fruit number increases, fruit oil content decreases (Table 5). Unsurprisingly, in these experiments, however, greatest oil production was obtained in CON with a combination of large fruit and high oil percentage (Table 3). Fruit number was not reduced relative to $\mathrm{CON}$ by deficit irrigation during July (DI-J), but interestingly that treatment did record the most fruits per bud (Table 2). Explanation of greater oil yield of DI-J relative to DI-JA and DI-A (Table 4) is found, therefore, in its greater oil percentage relative to those treatments (Table 3).

Oil production was significantly related with fruit (dry) biomass $\left(\mathrm{R}^{2}=0.88\right)$ (Table 5), but there was no response of fruit biomass to treatment in any individual year (Table 4). When taken together, however, CON produced more (5868 $\mathrm{kg} / \mathrm{ha}$ ) than the other treatments without significant 
difference between them (Table 4). Mean fruit biomass of DI-J, DI-A and DI-JA were 5243, 5096 and $5180 \mathrm{~kg} / \mathrm{ha}$, respectively. Despite a strong overall relationship between fruit biomass and fruit number/tree $\left(\mathrm{R}^{2}=0.57\right.$ ) (Table 5), CON did not have more fruit overall than the other treatments. In this experiment, the explanation of difference in fruit biomass is found in the response of fruit size to irrigation (Table 3). CON had larger fruit (0.61 g) than DI-J (0.49 g) or DI-JA (0.47). Fruits in DIA were larger $(0.56 \mathrm{~g})$ that DI-J and DI-JA, although not large enough to match biomass production of CON.

DI-J was the superior deficit-irrigation treatment because it was able to increase oil percentage to overcome reduced fruit biomass that it shared with the other deficit-irrigation treatments.

Table 5. Relationship between oil production and components of yield in a control and three deficitirrigation treatments. 130 data pairs were used.

\begin{tabular}{llll}
\hline Dependent variable (y) & Independent variable $(\mathrm{x})$ & Linear regression & $\mathrm{R}^{2}$ \\
\hline Oil production $(\mathrm{kg} / \mathrm{ha})$ & Olive fruits (number/tree) & $\mathrm{y}=0.09 \mathrm{x}+1181$ & 0.27 \\
\hline Oil production $(\mathrm{kg} / \mathrm{ha})$ & Oil content (g/fruit) & $\mathrm{y}=1741 \mathrm{x}+2015$ & 0.04 \\
\hline Oil production $(\mathrm{kg} / \mathrm{ha})$ & Oil content (\% dry matter) & $\mathrm{y}=74 \mathrm{x}-852$ & 0.22 \\
\hline Oil production $(\mathrm{kg} / \mathrm{ha})$ & Olive dry weight (g/fruit) & $\mathrm{y}=413 \mathrm{x}+2210$ & 0.01 \\
\hline Oil production (kg/ha) & $\begin{array}{l}\text { Olive production dry weight } \\
\text { (kg/ha) }\end{array}$ & $\mathrm{y}=0.47 \mathrm{x}-109$ & 0.88 \\
\hline Oil production (kg/ha) & $\begin{array}{l}\text { Olive production dry weight } \\
\text { excluding oil (kg/ha) }\end{array}$ & $\mathrm{y}=0.69 \mathrm{x}+350$ & 0.61 \\
\hline Oil content (\% dry matter) & Olive fruits (number/tree)/1000 & $\mathrm{y}=-0.03 \mathrm{x}+0.79$ & 0.54 \\
\hline Oil content (g/fruit) & Olive fruits (number/tree)/1000 & $\mathrm{y}=-28 \mathrm{x}+16$ & 0.45 \\
\hline Olive dry weight (g/fruit) & Olive fruits (number/tree)/1000 & $\mathrm{y}=-0.01 \mathrm{x}+0.42$ & 0.57 \\
\hline $\begin{array}{l}\text { Olive dry weight excluding } \\
\text { oil (g/fruit) }\end{array}$ & Olive fruits (number/tree)/1000 & $\mathrm{y}=-0.45 \mathrm{x}+48$ & 0.12 \\
\hline
\end{tabular}

\section{Oil yield in relation to irrigation}

Oil production in CON, DI-J and DI-JA increased linearly with irrigation each year (Fig. 3 ), while production in DI-A was, in each year, $10 \%$ below the corresponding production for amount of irrigation applied.

The amount of irrigation water applied to the various treatments varied substantially from year to year as did the proportion of CON that was saved by the deficit-irrigation treatments (Table 1). Analysis of water saving is therefore made most appropriately as proportion of full water requirement, rather than absolute amounts of water saved, as presented in Table 1. In this way, analysis reveals seasonal water savings ranging from 16 to $31 \%$ and that DI-J, the deficit-irrigation treatment that best maintained yield, saved least water (mean 16\%) because, during that treatment, soil contained water remaining from spring rainfall. In contrast, DI-JA was the treatment that saved more water (27\%). A strong relationship $\left(\mathrm{R}^{2}=0.86\right)$ was observed between loss of oil production and water saving in the summer deficit treatments, DI-A and DI-J (Fig. 4). In DI-JA, oil production was reduced by $15 \%$ at a saving of $50 \%$ summer water. DI-A and DI-J would save $35 \%$ water for the same loss of oil production. Calculations of Irrigation Water Productivity (oil production per irrigation) show that DI-JA was more efficient $\left(1.18 \pm 0.67 \mathrm{~kg} / \mathrm{m}^{3}\right)$ than the other irrigation treatments, CON $(0.97 \pm 0.48)$, DI-J $(1.07 \pm 0.54)$ and DI-A (1.01 \pm 0.56$)$.

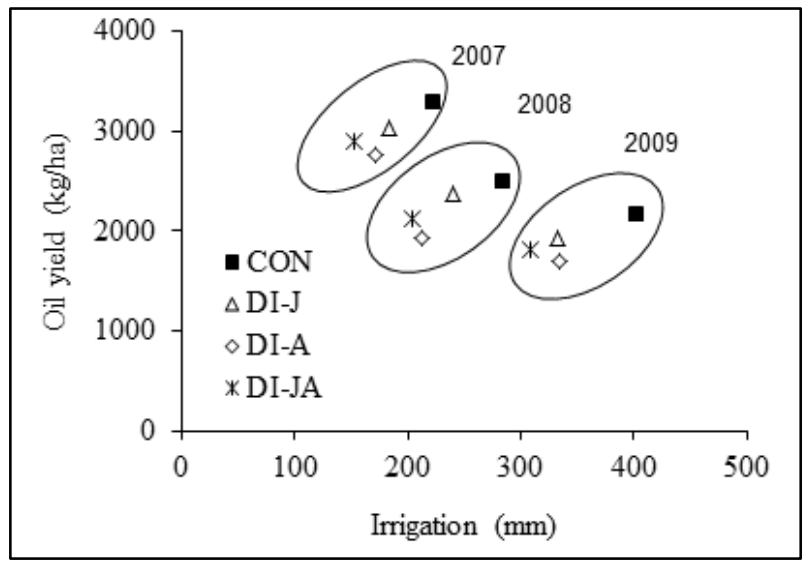

Figure 3. Relationship between oil yield and irrigation in a control (CON) and three deficit-irrigation treatments (DI-J, DI-A and DI-JA). Values are means of 12 replicates.

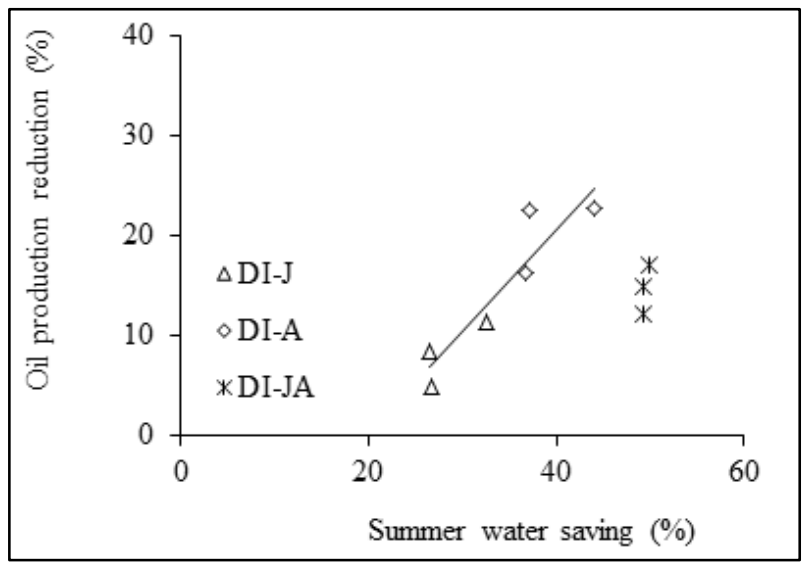

Figure 4. Relationship between oil yield reduction and summer water saving compared to control (CON) in three deficit-irrigation treatments (DI-J, DI-A and DIJA). Values are means of 12 replicates. Regression: $\mathrm{y}=$ $\mathrm{X}-20\left(\mathrm{R}^{2}=0.86\right)$. 


\section{Discussion}

RDI is a strategy based on the physiology of tree growth and different response to different intensity of water deficit in various periods. The experiment was carried out in an orchard located in Mediterranean climate, where rainfall occurs mainly in spring and autumn. Olive trees evolved in, and are well adapted to, this rainfall distribution and are most sensitive to water shortage during these two periods. Olive is most drought resistant during the summer period, this is from the end of fruit drop to beginning of oil synthesis. Meanwhile oil production was increased (Fig. 3) when irrigation was applied in summer, as previously reported by Fernandez and Moreno (1999) and Pastor (2005). But in this case, differences were found in orchard production and fruit characteristics when severe RDI was applied at the beginning of summer (DI-J), at the end of summer (DI-A), or when less severe deficit irrigation was applied throughout the summer period (DI-JA).

Climatic conditions and cultivar determined the experimental results. 'Arbequina' has little tendency for alternate bearing when harvested early (Barranco et al. 2005) so differences between experimental years in olive production (Table 4) can be largely attributed to climatic conditions (Fig. 1), specifically winter and autumn temperatures and rainfall. The experimental orchard is located on the high plateau $(516 \mathrm{~m}$ a.s.l.) of Central Spain where freezing autumn temperatures, to $-7^{\circ} \mathrm{C}$ in November, are common. This explains loss of production in 2009 when temperatures down to $-10.2^{\circ} \mathrm{C}$ provoked tree defoliation. Early harvesting is important for high yield and oil quality. In these experiments fruits were harvested with average maturity indexes of 3.0, 0.4 and 1.5 in 2007, 2008 and 2009, respectively (Table 3 ) compared to full maturity of 3.0 in this cultivar. For these harvests, average oil concentrations ( $\%$ dry matter) were $47.5,41.6$, and $44.3 \%$. In addition to its effect on alternate bearing (Rallo and Cuevas 2008), early harvest also reduces oil production because average oil content per dry weight increases by around 1.5\% for each week approaching maturity (Fig. 2).

Annual and summer rainfall determined the effect of irrigation treatments. In 2007, the year of highest summer rainfall, there were no significant differences in most observed parameters. By contrast, irrigation treatments significantly modified fruit characteristics in both other years. Autumn rainfall determined olive fruit water content and oil content per fresh weight. In 2008 autumn rainfall provoked fruits with high water and low oil content compared with the other years (Table 3). With that combination, oil extractability was also low. Nevertheless summer irrigation treatments significantly determined fruit characteristics at harvest and yield. Because the responses were highly depended on seasonal conditions, effects of irrigation treatment must be analyzed individually for each year.

Fruit growth and development between September and harvest (Fig. 2) were similar to those observed by Gucci et al. (2009) and Hartmann (1949). After the treated period, olive weight and oil content increased sharply during September and until the end of October and then slowed until harvest. Weekly oil content per dry weight increased 3.7 and $1.5 \%$ before and after the end of October, respectively. During this period, $9 \%$ of final non-oil fruit dry matter was accumulated but $86 \%$ of final oil content was synthesized. Summer irrigation did not modify this autumn pattern and differences in fruit dry matter and oil content were maintained along the oil synthesis period until harvest (Table 3). Water deficit in July (DI-J) significantly reduced fruit size compare to CON, while oil content per dry matter was the highest (Table 3). Rapoport et al. (2004) observed that water stress during pit hardening provoked smaller pits and a greater pulp/pit ratio. Considering that oil is mainly contained in pulp, this could explain the high oil content per dry weight of DI-J olives. Delayed pit hardening, observed in 2008 and 2009, may support this hypothesis. Oil content per dry weight was reduced when irrigation deficit was applied during August (DI-A) or July and August (DI-JA). The amount of oil per fruit was reduced when deficit-irrigation deficit was applied all summer (DI-JA). Irrigation deficit in August (DI-A) did not significantly modify olive dry matter production but when applied in July (DI-J) or July and August (DI-JA) fruit dry matter at harvest was significantly less than control (CON).

Significant to interpretation of observed yield responses, all deficit-irrigation treatments studied (DI-A, DI-J and DI-JA) received the same amount of water as the control (CON) during spring and autumn. Deficit-irrigation treatments during summer may affect orchard oil production by modifying fruit drop, fruit size, floral initiation or oil synthesis depending upon timing of application. Although floral induction starts in mid summer, around pit hardening, and finishes in autumn 
(Rallo and Cuevas 2008), DI-J enhanced flower initiation such that in 2009 there were significantly more fruits per bud compared to DI-A (Table 2). Gucci et al. (2007) observed that severe water stress during summer and autumn increased inflorescences per flowering shoot. Fruit number was highest in DI-J but not significantly different to the other irrigation treatments (Table 4). The dominance of fruit number as the parameter that determines oil production (Table 5) is due to the amount of mesocarp developed by a tree (Lavee and Wodner 2004). It has also been observed in other irrigation experiments (Ben-Gal et al. 2011; Correa-Tedesco et al. 2010; Fernandes-Silva et al. 2010; Moriana et al. 2003).

This experiment sought answer to the question of how oil production and its components respond to different summer RDI strategies (intensities and periods). The results reveal that mild deficit throughout summer (DI-JA) or severe deficit in August (DI-A) reduced oil production relative to CON, but by different mechanisms. In the first case the effect operated through fruit size and oil content and in the second through oil content alone. DI-A developed bigger fruits with less oil content (\%) than DI-JA. In contrast, early irrigation deficit in July (DI-J) had no effect on oil production in any of the experimental years, although the smaller fruits had higher oil concentration (\%). Goldhamer (1999) and Lavee et al. (2007) have previously observed that deficit irrigation near pit hardening did not reduce yield. The explanation of greater oil yield in DI-J relative to DI-A and DI-JA (Table 5) is found partly in higher oil content (Table 3) but mainly in more fruits (Table 4).

The objective of RDI is to save water with least loss in oil production, none if possible. In this experiment, most water saving (27\%) was achieved by DI-JA that reduced irrigation by $50 \%$ during July and August while decreasing production by $15 \%$. Similar water saving of $22 \%$ was achieved in DI-A by a large reduction of $70 \%$ in applied water during August that reduced oil production by $21 \%$. By comparison, DI-J is the most interesting strategy under the prevailing environmental conditions. By reducing irrigation by $70 \%$ in early summer (July) it was able to save $16 \%$ of total season irrigation water without loss of oil production relative to CON (oil yield was reduced by $8 \%$ less but was not significant).

\section{Conclusion}

During the period from the end of fruit drop until the beginning of oil synthesis (summer period) irrigation water can be saved with little effect on oil production. However, special attention must be paid to how the deficit is applied. Severe deficit irrigation in July (DI-J) is the most suitable RDI strategy, but water saving is small because of high soil water content remaining from spring rainfall. Regulated Deficit Irrigation applied in July (DI-J) allowed production of very high yield (2447 kg/ha of oil, mean of three years) by irrigating with $253 \mathrm{~mm}$ of water even though rainfall was low (359 mm/year) and ETo high (1282 mm/year) during the experimental years. More water can be saved by continuous, less severe deficit irrigation during July and August (DI-JA) and be achieved with more oil production than by severe deficit irrigation in August (DI-A) for similar water saving. Severe deficit irrigation in August, just before oil synthesis period starts, is not a suitable strategy for olive even though much water can be saved because evaporative demand (ETo) is high.

\section{Acknowledgements}

I gratefully acknowledge Agrícola La Veguilla for access to the olive orchard. I express my gratitude to David J. Connor for suggestions on the manuscript, Vicente Gómez for the soil description, Miguel Benito, Ana Centeno, and Enrique Vivas for helping in field data collection. I gratefully acknowledge the suggestions of three reviewers.

\section{Literature Cited}

Allen RG, Pereira LS, Raes D, Smith M (1998) Crop evapotranspiration. Guidelines for computing crop water requirements. Irrigation and drainage paper 56. FAO, Rome, Italy.

Barranco D, Trujillo I, Rallo L (2005) Libro I. Elaiografía hispánica. In: Rallo L, Barranco D, Caballero JM, del Rio C, Martin A, Tous J, Trujillo I (eds.)Variedades de olivo en España. Junta de Andalucía, MAPA and Ediciones Mundi-Prensa, Madrid, Spain.

Ben-Gal A, Yermiyahu U, Zipori I, Presnov E, Hanoch E, Dag A (2011) The influence of bearing cycles on olive oil production response to irrigation. Irrig Sci 29, 3:253-263. 
Chalmers DJ, Mitchell PD, Vanheek L (1981) Control of peach-tree growth and productivity by regulated water-supply, tree density, and summer pruning. J Am Soc Hort Sci 106, 307-312.

Connor DJ (2005) Adaptation of olive (Olea europaea L.) to water-limited environments. Aust J of Agric Res 56:1181-1189.

Correa-Tedesco G, Rousseaux MC, Searles PS (2010) Plant growth and yield responses in olive (Olea europaea) to different irrigation levels in an arid region of Argentina. Agric Water Manag 97,11:1829-1837.

del Rio C, Romero AM (1999) Whole, unmilled olives can be used to determine their oil content by Nuclear Magnetic Resonance. HortTechnology 9, 675-680.

Fernandes-Silva AA, Ferreira TC , Correia CM , Malheiro AC, Villalobos FJ (2010) Influence of different irrigation regimes on crop yield and water use efficiency of olive. Plant and soil 333: 35-47.

Fernandez JE, Moreno F (1999) Water use by the olive tree. J Crop Prod 2:101 - 162.

Ferreira J (1979) Explotaciones olivareras colaboradoras $\mathrm{n}^{\circ} 5$. Ministerio de Agricultura, Madrid. Spain

Goldhamer DA (1999) Regulated deficit irrigation for California canning olives. Acta Hort 474:369-372.

Grattan SR, Berenguer MJ, Connell JH, Polito VS, Vossen PM (2006) Olive oil production as influenced by different quantities of applied water. Agric Water Manag 85:133-140.

Gucci R, Lodolini E, Rapoport HF (2007) Productivity of olive trees with different water status and crop load. J Hort Sci Biotech 82:648-656.

Gucci R, Lodolini E, Rapoport HF (2009) Water deficit-induced changes in mesocarp cellular processes and the relationship between mesocarp and endocarp during olive fruit development. Tree Physiol 29:1575-1585.

Hartmann HT (1949) Growth of the olive fruit. Proc of the Am Soc Hortic Sci 54:86-94.

Lavee S, Wodner M (2004) The effect of yield, harvest time and fruit size on the oil content in fruits of irrigated olive trees (Olea europaea), cvs. 'Barnea' and 'Manzanillo'. Sci Hortic 99:267-277.

Lavee S, Hanoch E, Wodner M, Abramowitch H (2007) The effect of predetermined deficit irrigation on the performance of cv. 'Muhasan' olives (Olea europaea L.) in the eastern coastal plain of Israel. Sci Hortic 112:156163.

Martin-Vertedor AI, Perez JM, Prieto H, Fereres $\mathrm{E}$ (2011) Interactive responses to water deficits and crop load in olive (Olea europaea L., cv. Morisca). II: Water use, fruit and oil yield. Agric Water Manag 98:950-958.

Morettini A (1972). Olivicoltura. Ramo Editoriale Degli Agricoltori, Rome, Italy.

Moriana A, Orgaz F, Pastor M, Fereres E (2003) Yield responses of a mature olive orchard to water deficits. J Am Soc Hort Sci 128:425431.

Motilva MJ, Tovar MJ, Romero MP, Alegre S, Girona J (2000) Influence of regulated deficit irrigation strategies applied to olive trees ('Arbequina' cultivar) on oil yield and oil composition during the fruit ripening period. J Sci Food and Agric 80:2037-2043.

Orlandi F, Msallem M, Bonofiglio T, Ben Dhiab A, Sgromo C, Romano B , Fornaciari M (2010) Relationship between olive flowering and latitude in two Mediterranean countries (Italy and Tunisia) M.). Theor Appl Climatol 102:265-273.

Pastor M (2005) Cultivo del olivo con riego localizado. Mundi-Prensa, Madrid, Spain.

Patumi M, d'Andria R, Marsilio V, Fontanazza G, Morelli G, Lanza B (2002) Olive and olive oil quality after intensive monocone olive growing (Olea europaea L., cv. 'Kalamata') in different irrigation regimes. Food Chem 77:27-34.

Rallo L, Cuevas J (2008) Fructificación y producción. In: Barranco D, FernandezEscobar R, Rallo L (eds.) El cultivo del olivo. Mundi-Prensa, Madrid, Spain.

Rapoport HF, Costagli G, Gucci R (2004) The effect of water deficit during early fruit development on olive fruit morphogenesis. J Am Soc Hort Sci 129:121-127. 
Ruiz-Sanchez MC, Domingo R, Castel JR (2010)

Review. Deficit irrigation in fruit trees and vines in Spain. Span J Agric Res 8:S5-S20.

Sanz-Cortes F, Martinez-Calvo J, Badenes ML, Bleiholder H, Hack H, Llacer G, Meier U (2002) Phenological growth stages of olive trees (Olea europaea). Ann Appl Biol 140:151-157.
Tognetti R, d'Andria R, Lavini A, Morelli G (2006) The effect of deficit irrigation on crop yield and vegetative development of Olea europaea L. (cvs. 'Frantoio' and 'Leccino'). Eur J Agron 25:356-364. 